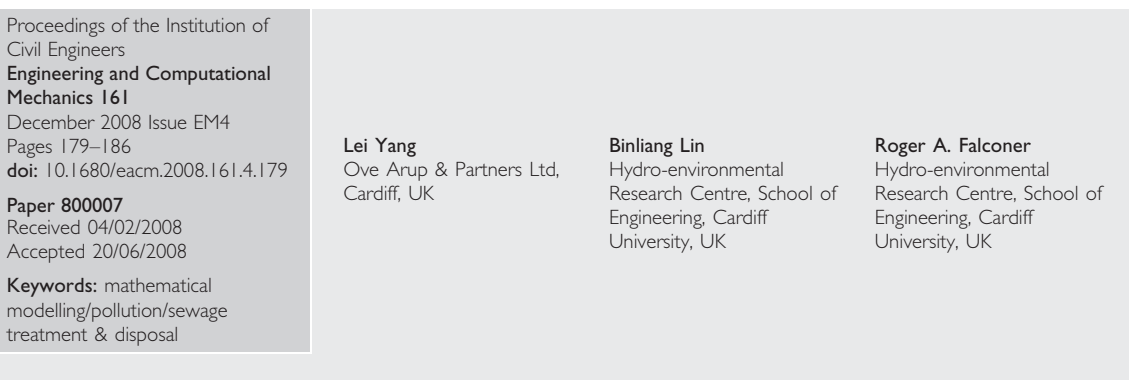

\title{
Modelling enteric bacteria level in coastal and estuarine waters
}

L. Yang MPhil, PhD, B. Lin CEng, DEng, PhD and R. A. Falconer DSc(Eng), FREng, FICE, FCGI

Details are given in this paper of the development of a numerical model for describing the bacterial transport processes in estuarine and coastal waters. The transport of enteric bacteria is influenced by many physical, chemical and biological factors, including both the suspended and bed sediments. In recent years, an increasing number of studies have shown that generally the sediments contain much higher bacterial population levels than previously assumed. The aim of this study has been to develop a numerical modelling tool for predicting the sediment-linked bacterial concentration levels in coastal and estuarine waters. This paper outlines the theoretical background of an enteric bacterial water quality numerical model. A conceptual model has been established for representing the transport of bacteria due to sediment movement, including deposition and suspension. Details are given of the solute and mass transport equations used to simulate the flow and transport of suspended sediments and enteric bacterial indicators. The enteric bacteria transport equation includes enhanced source and sink terms to represent bacterial kinetic transformation and disappearance or reappearance due to sediment deposition or resuspension. The model has been applied to the turbid water environment in the Bristol Channel and Severn estuary, UK, with initial results from the modelling study being presented.

\section{NOTATION}

$A_{0} \quad$ horizontal outfall discharge area

a reference level

C bacterial concentration (cfu/100 ml)

$C_{\mathrm{b}}$ bacterial concentration on bed sediments (cfu/g)

$C_{\mathrm{b} 0} \quad$ initial bacteria concentration on the bed sediments (cfu/g)

$C_{\mathrm{d}} \quad$ rate of bacterial concentration disappearance

$C_{0} \quad$ outfall discharge concentration (cfu/100 ml)

$C_{\mathrm{r}} \quad$ rate of bacterial concentration increase

D deposition rate $\left(\mathrm{kg} / \mathrm{m}^{2} / \mathrm{s}\right)$

$D_{50}$ sediment diameter of which $50 \%$ of the bed material is finer

D* particle parameter

$\mathrm{d} S_{\mathrm{d}} / \mathrm{d} t$ change rate in suspended sediments concentration caused by the settling process $\left(\mathrm{kg} / \mathrm{m}^{3} / \mathrm{s}\right)$

$\mathrm{d} S_{\mathrm{r}} / \mathrm{d} t$ increase rate of suspended sediments concentration due to resuspension $\left(\mathrm{kg} / \mathrm{m}^{3} / \mathrm{s}\right)$
E resuspension rate $\left(\mathrm{kg} / \mathrm{m}^{2} / \mathrm{s}\right)$

$H \quad$ water depth

$K \quad$ specific decay rate $\left(\mathrm{s}^{-1}\right)$

$k_{\mathrm{b}} \quad$ decay rate of bacteria existing in the bed sediments $\left(\mathrm{s}^{-1}\right)$

$k_{\mathrm{d}} \quad$ die-off coefficient for dark conditions

$k_{\mathrm{p}} \quad$ predation coefficient

$k_{\mathrm{r}} \quad$ die-off coefficient resulting from radiation

$k_{\mathrm{S}} \quad$ settling coefficient

$M \quad$ empirical constant with appropriate units $\left(\mathrm{kg} / \mathrm{m}^{2} / \mathrm{s}\right)$.

$N \quad$ number of outfalls.

$Q_{0} \quad$ outfall discharge rate

$S \quad$ suspended sediments concentration $\left(\mathrm{kg} / \mathrm{m}^{3}\right)$

$S_{a} \quad$ sediment concentration at a reference level $a$

$S_{a \mathrm{e}} \quad$ equilibrium sediment concentration at the reference level $a$

$S_{\mathrm{b}} \quad$ near-bed cohesive sediment concentration $\left(\mathrm{kg} / \mathrm{m}^{3}\right)$

$S_{\mathrm{e}} \quad$ depth mean equilibrium concentration

$T$ temperature $\left({ }^{\circ} \mathrm{C}\right)$

$T$ transport stage parameter

$t \quad$ time (s)

$w_{\mathrm{s}} \quad$ sediment settling velocity $(\mathrm{m} / \mathrm{s})$

$\alpha_{\mathrm{s}} \quad$ population ratio of attached bacteria to total bacteria existing in the water column

$\theta \quad$ Arrhenius constant

$\Sigma \Phi_{\text {s }} \quad$ source or sink term, representing the input sources and all kinetic transformations of bacteria in the water environment

$\boldsymbol{T}_{\mathrm{b}} \quad$ effective bottom shear stress $\left(\mathrm{N} / \mathrm{m}^{2}\right)$

$\boldsymbol{T}_{\mathrm{c}} \quad$ critical shear stress for sediment erosion $\left(\mathrm{N} / \mathrm{m}^{2}\right)$

$\boldsymbol{T}_{\mathrm{d}} \quad$ critical shear stress beyond which there is no further deposition $\left(\mathrm{N} / \mathrm{m}^{2}\right)$

\section{INTRODUCTION}

The study of the survival of enteric bacteria by using indicators such as total coliforms, faecal coliforms and faecal streptococci, has been an important subject in the research field of coastal water quality control for many years. ${ }^{1-5}$ Furthermore, the disappearance of faecal bacteria in natural waters has generally been assumed to follow a first-order decay formulation according to Chick's law ${ }^{6}$

$$
\frac{\mathrm{d} C}{\mathrm{~d} t}=-k C
$$


where $C$ is the bacterial concentration (colony-forming units (cfu)/100 ml); $t$ is time (s); and $k$ is the specific decay rate $\left(\mathrm{s}^{-1}\right)$.

From the literature it can be seen that many investigations have been undertaken by a number of researchers to determine the values and variability of decay rate. ${ }^{3,4,7,8}$ These studies have generally shown that the value of $k$ is affected by many interacting factors, including: the sunlight intensity, the levels of salinity, turbidity, temperature, algal toxins, heavy metals, $\mathrm{pH}$, protozoa, bacteriophages, predation, organic matter and nutrients, and the suspended sediment concentration levels.

Although in some of these studies the effects of sedimentation on the disappearance of bacteria have been reported, ${ }^{9-12}$ there is little detailed knowledge on how these effects can be described in a quantitative manner. Sedimentation can result in a certain amount of the bacteria being removed from the water column by adsorbing onto the bed sediments. Up to now the representation of this process has been mainly through the first-order decay equation, in which the overall disappearance, or die-off rate constant $K$, is generally written as ${ }^{13}$

\begin{tabular}{|l|l|}
\hline 2 & $K=\left(k_{r}+k_{d}+k_{s}+k_{p}\right) \theta^{(T-20)}$ \\
\hline
\end{tabular}

where $k_{\mathrm{r}}$ is the die-off coefficient resulting from radiation; $k_{\mathrm{d}}$ is the die-off coefficient for dark conditions; $k_{\mathrm{s}}$ is the settling coefficient; $k_{\mathrm{p}}$ is the predation coefficient; $\theta$ is the Arrhenius constant and $T$ is temperature $\left({ }^{\circ} \mathrm{C}\right)$.

Previous studies ${ }^{9,10,14}$ have demonstrated that the settling coefficient $k_{\mathrm{s}}$ is one of the controlling factors that affect the bacterial level in the water column, and this process is generally represented using the first-order decay rate, as given in equation (2). However, sedimentation is the physical process of suspended sediments (SS) being moved out from the water column to the bed by the action of gravity. Similarly, bed sediments can be entrained into the overlying water column by turbulence through resuspension. It is well known that the settling/resuspension rate depends on both the flow regime and the characteristics of the sediments, including particle size, density and concentration. Thus, the bacterial disappearance rate due to sedimentation does not generally follow a simple first-order decay formulation. Therefore any quantitative formulation to describe the reduction in the bacterial population due to the settling effects should include the settling processes in the formulation.

In natural waters sediments may deposit in any local location, and these deposited particles will act as a temporary or longterm sink for pollutants associated with them. When modelling the bacterial transport in estuarine and coastal waters another important issue to be considered is the periodical resuspension of bacteria with sediments from the bed. The resuspension of sediment-bound indicator bacteria, which may cause significant public health hazards in the overlying water column, has been well documented in many studies. ${ }^{12,15,16}$ It has also been found that the bacteria population in the bed sediments is generally much higher than that in the water column, with the bed sediment population being typically between 100-2000 times greater. ${ }^{17-22}$ Therefore, sediment resuspension can provide a significant source of bacteria from the bed sediments to the water column. Little information can be found in the literature, however, regarding modelling this kind of resuspension.

Therefore in the present study two types of governing equations have been used to describe the total disappearance of bacteria from the water column. These include bacteria die-off based on a first-order decay and bacterial disappearance due to sedimentation. The main objective of the present study was to develop a model representation of the bacterial disappearance rate due to the deposition of suspended sediments and the bacterial increase rate due to the resuspension of the bed sediments. A new numerical modelling approach has been developed for solving the governing equations of the enteric bacteria transport process associated with the suspended sediment fluxes. This approach relates the bacterial inputs to an additional source term associated with the resuspension of the bed sediments, while all of the other sources have been considered in the usual way. Furthermore, the bacterial die-off and sedimentation disappearance fluxes have been calculated separately by employing two different sink terms.

The refined numerical model has been applied to the Bristol Channel and Severn estuary, UK, to study the general waterquality characteristics of the basin and, in particular, the relative influence of the bed sediments on the receiving water bacterial levels. Initial results from the modelling study are presented.

\section{CONCEPTUAL MODEL OF BACTERIA TRANSPORT}

\section{I. The existence of bacteria in natural waters}

Bacteria in natural waters exist in two forms, one as free-living bacteria and the other as attached bacteria that are adsorbed onto the surface of sediment particles. ${ }^{23}$ The free-living bacteria move with the flow, whereas the attached bacteria move with the suspended sediments, which may settle on the bed or be resuspended into the flow field.

Rapid urbanisation has rendered natural waters increasingly turbid, which provides more scope for bacteria to survive within the sediments. Marshall ${ }^{17}$ indicated that bacteria were readily adsorbed onto different kinds of interfaces, such as liquid-solid, liquid-liquid, liquid-gas, etc. and most of them were attached to these surfaces. He also quoted the results from Jannasch who found that only $0 \cdot 02 \%$ of the microbial population in the Nile River was planktonic, with the remainder being attached to mineral particulate materials. Harvey et al. ${ }^{24}$ reported that in an aquifer contaminated with treated sewage, $96 \cdot 8-100 \%$ of the bacteria were sedimentbound when enumerated by direct counting (acridine orange direct counting; AODC). In addition, Albrechtsen ${ }^{25}$ found that most of the bacteria and their activity were associated with small particles and only $0 \cdot 01 \%$ of the total bacteria number was counted to be free-living in the pore water.

\subsection{Bacteria transport in water}

In coastal and estuarine waters enteric bacteria derive from (see Figure 1) the following sources 


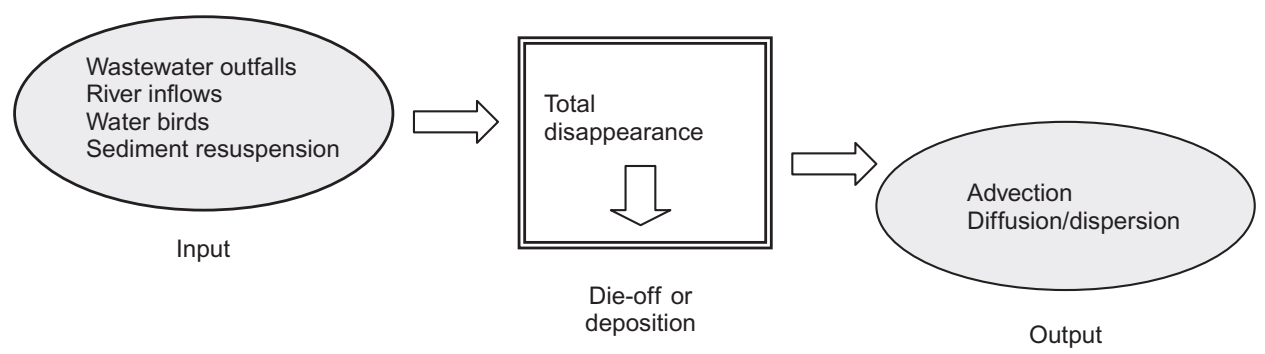

Figure I. Conceptual model of enteric bacteria transport in natural waters

(a) direct sewage disposals via sea outfalls of wastewater treatment plant, and so on

(b) indirect sewage disposal and diffuse inputs from inland settlements via riverine inflows

(c) disposals from wildlife populations; for example, water birds forage in the sea or river water and sometimes on the intertidal beaches

(d) bed sediment resuspension, which can also be considered as a bacterial source.

Figure 1 shows that the reduction of bacteria in natural waters can be divided into two categories, namely die-off (or inactivation) and deposition. It also shows that sediment resuspension is regarded as one of the key bacterial sources, with this source potentially being important in bathing water non-compliance.

\subsection{Relationship between bacteria and suspended sediment deposition}

In developing formulations to describe the relationships between enteric bacteria levels and suspended sediment concentrations in natural waters, the following assumptions have been made.

(a) Once a batch of bacteria enter the computational water column (or control volume), a percentage of them is immediately adsorbed onto the surface of suspended solids.

(b) There are sufficient suspended sediment particles in the water column to provide living places for the bacteria in the water column.

(c) Within the water column the distribution of suspended sediment concentrations and bacterial populations are uniform over the water depth.

With these assumptions, the rate of bacterial concentration disappearance caused by the settling of suspended sediment can be described by the following expression

\begin{tabular}{|c|c|}
\hline 3 & $\frac{\mathrm{d} C_{\mathrm{d}}}{\mathrm{d} t}=\alpha_{\mathrm{s}} \frac{C}{S} \frac{\mathrm{d} S_{\mathrm{d}}}{\mathrm{d} t}$ \\
\hline
\end{tabular}

where $\mathrm{d} C_{\mathrm{d}} / \mathrm{d} t$ is the rate of bacterial concentration disappearance; $S$ is the suspended sediment concentration $\left(\mathrm{kg} / \mathrm{m}^{3}\right) ; \mathrm{d} S_{\mathrm{d}} / \mathrm{d} t$ is the change rate in suspended sediment concentration caused by the settling process $\left(\mathrm{kg} / \mathrm{m}^{3} / \mathrm{s}\right) ; \alpha_{\mathrm{s}}$ is the population ratio of attached bacteria to total bacteria existing in the water column.

\subsection{Relationship between bacteria and sediment resuspension}

In coastal and estuarine waters, the resuspension of the bed sediments tends to occur periodically due to tidal currents, and the increase rate in indicator bacterial concentrations caused by this process can be expressed as

$4 \quad \frac{\mathrm{d} C_{\mathrm{r}}}{\mathrm{d} t}=0 \cdot 1 C_{\mathrm{b}} \frac{\mathrm{d} S_{\mathrm{r}}}{\mathrm{d} t}$

where $\mathrm{d} C_{\mathrm{r}} / \mathrm{d} t$ is the rate of bacterial concentration increase; $C_{\mathrm{b}}$ is the bacterial concentration on bed sediments (cfu/g); $\mathrm{d} S_{\mathrm{r}} / \mathrm{d} t$ is the increase rate of suspended sediment concentration due to resuspension $\left(\mathrm{kg} / \mathrm{m}^{3}\right)$; and $0 \cdot 1$ is a constant produced from the change of units between $C_{\mathrm{b}}$ and $C_{\mathrm{r}}$.

The kinetics of the bacterial survival in the bed sediments is assumed to follow the first-order decay equation, giving

5

$$
C_{\mathrm{b}}=C_{\mathrm{b} 0} \mathrm{e}^{-k_{\mathrm{b}} t}
$$

where $C_{\mathrm{bo}}$ is the initial bacteria concentration on the bed sediments ( $\mathrm{cu} / \mathrm{g})$; and $k_{\mathrm{b}}$ is the decay rate of bacteria existing in the bed sediments $\left(\mathrm{s}^{-1}\right)$.

\section{SEDIMENT TRANSPORT MODEL}

The sediment transport in natural waters is governed by the sediment characteristics and flow motion. Once suspended in the water, sediments are transported with the flow flux and they always tend to settle down due to gravity. The settled bottom sediments later could also re-enter the water column due to turbulence.

The resuspension of bed sediments will only occur in the flowing water when the disturbance is strong enough to bring the bed sediments into the water column. Once the characteristics of the sediment have been defined, the bottom shear stress at the sediment-water interface is the controlling factor determining the amount of sediments into resuspension. 


\section{I. Cohesive sediment transport in coastal waters}

In modelling the sediment transport in coastal waters, it is common to consider cohesive sediments, as the effluents from sewage and wastewater treatment works (WwTW) outfalls normally contain fine and flocculated particles. Many studies $^{26-28}$ have focused on investigating the deposition and resuspension rates of cohesive sediments.

A key parameter in modelling sediment transport is the sediment flux $\boldsymbol{q}_{\mathrm{s}}$ at the sediment-water interface in the water column. The cohesive sediment net flux $\boldsymbol{q}_{\mathrm{s}}$ can be written as

\begin{tabular}{|l|l|}
\hline 6 & $q_{s}=E-D$ \\
\hline
\end{tabular}

where $\boldsymbol{E}$ is the resuspension rate $\left(\mathrm{kg} / \mathrm{m}^{2} / \mathrm{s}\right)$ and $\boldsymbol{D}$ is the deposition rate $\left(\mathrm{kg} / \mathrm{m}^{2} / \mathrm{s}\right)$.

In equation (6) the assumption made is that the resuspension and deposition are independent processes; that is, $\boldsymbol{E}$ is the sediment flux when no suspended sediment deposition is present, and $\boldsymbol{D}$ is the sediment flux in the absence of resuspension. When $\boldsymbol{q}_{\mathrm{s}}=0$, the equation indicates that there is a dynamic equilibrium at the sediment-water interface between the entrainment and deposition.

A linear mathematical formulation widely employed in many resuspension rate $(E)$ studies $^{29,30}$ is adopted in this study wherein

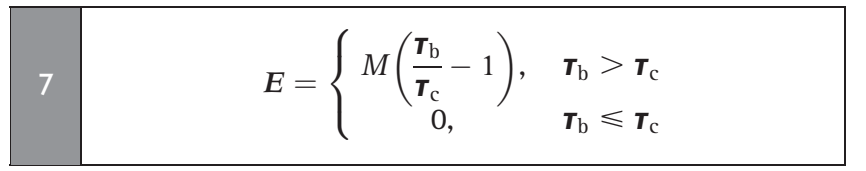

where $\boldsymbol{T}_{\mathrm{b}}$ is the effective bottom shear stress $\left(\mathrm{N} / \mathrm{m}^{2}\right) ; \boldsymbol{T}_{\mathrm{c}}$ is the critical shear stress for sediment erosion $\left(\mathrm{N} / \mathrm{m}^{2}\right)$; and $M$ is the empirical constant with appropriate units $\left(\mathrm{kg} / \mathrm{m}^{2} / \mathrm{s}\right)$.

Considering the total amount of resuspension $\boldsymbol{E}$ per unit bed area to be uniformly distributed over the water depth $H$, the instantaneous resuspension rate then becomes

$$
\frac{\mathrm{d} S_{\mathrm{r}}}{\mathrm{d} t}=\frac{E}{H}=\left.\frac{M}{H}\left(\frac{\boldsymbol{T}_{\mathrm{b}}}{\boldsymbol{T}_{\mathrm{c}}}-1\right)\right|_{\boldsymbol{T}_{\mathrm{b}}>\boldsymbol{T}_{\mathrm{c}}}
$$

Following Einstein and Krone, ${ }^{31}$ the deposition rate in equation (6) is written as

$$
9 \quad \boldsymbol{D}=\left\{\begin{array}{cl}
\boldsymbol{w}_{\mathrm{S}} S_{\mathrm{b}}\left(1-\frac{\boldsymbol{T}_{\mathrm{b}}}{\boldsymbol{T}_{\mathrm{d}}}\right), & \boldsymbol{T}_{\mathrm{b}}<\boldsymbol{T}_{\mathrm{d}} \\
0, & \boldsymbol{T}_{\mathrm{b}} \geqslant \boldsymbol{T}_{\mathrm{d}} \\
\hline
\end{array}\right.
$$

where $\boldsymbol{D}$ is the deposition rate $\left(\mathrm{kg} / \mathrm{m}^{2} / \mathrm{s}\right) ; \boldsymbol{w}_{\mathrm{s}}$ is the sediment settling velocity $(\mathrm{m} / \mathrm{s}) ; S_{\mathrm{b}}$ is the near-bed cohesive sediment concentration $\left(\mathrm{kg} / \mathrm{m}^{3}\right) ; \boldsymbol{T}_{\mathrm{d}}$ is the critical shear stress beyond which there is no further deposition $\left(\mathrm{N} / \mathrm{m}^{2}\right)$; and $\boldsymbol{T}_{\mathrm{b}}$ is the effective bottom shear stress $\left(\mathrm{N} / \mathrm{m}^{2}\right)$.

Since a uniform distribution of suspended sediments concentration has been assumed over the water depth then the reduction rate in suspended sediment concentration due to deposition of cohesive sediment is given as

$$
10 \quad \frac{\mathrm{d} S_{\mathrm{d}}}{\mathrm{d} t}=\frac{\boldsymbol{D}}{H}=\left.\frac{\boldsymbol{w}_{\mathrm{s}} S_{\mathrm{b}}}{H}\left(1-\frac{\boldsymbol{T}_{\mathrm{b}}}{\boldsymbol{T}_{\mathrm{d}}}\right)\right|_{\boldsymbol{T}_{\mathrm{b}}<\boldsymbol{T}_{\mathrm{d}}}
$$

\subsection{Non-cohesive sediment transport in coastal waters} The paradigm of cohesive sediment transport modelling is that erosion and deposition are mutually exclusive. Many laboratory studies have shown that there is a velocity/stress threshold below which erosion does not occur, and a lower threshold above which deposition does not occur. In contrast, a deposition threshold is not included in non-cohesive sediment transport models, allowing erosion and deposition to occur simultaneously. ${ }^{32-34}$

For this scenario sediments are transported initially as bedload, which implies a continual exchange between deposited and suspended particles. This bedload layer, which is considered always to be in equilibrium with the bottom shear stress, serves as the source layer for suspended sediments. Net erosion or net deposition occurs as the suspended load adjusts to the increase or decrease in the bedload concentration. The implementation of non-cohesive sediment transport modelling in this study follows van Rijn's formulae. ${ }^{35,36}$

The non-cohesive sediment net erosion or deposition rate $\boldsymbol{E}$ can be expressed as ${ }^{37}$

$$
\text { II } \quad E=w_{\mathrm{s}}\left(S_{a \mathrm{e}}-S_{\mathrm{a}}\right)
$$

where $S_{a}$ is the sediment concentration at a reference level $a$; $S_{a \mathrm{e}}$ is the equilibrium sediment concentration at the reference level $a$; and $a$ is the reference level, which was assumed to be equal to the equivalent roughness height.

For the cases in which $S_{\text {ae }}<S_{a}$ and $E<0$, deposition will occur; if $S_{a \mathrm{e}}>S_{a}$ and $E>0$, erosion will occur; and if $S_{a \mathrm{e}}=S_{a}, E=0$, then the system will be in equilibrium.

To calculate $S_{a \text { e, }}$ an expression given by van $\operatorname{Rijn}^{35}$ was used in the present study

$$
S_{a \mathrm{e}}=0.015 \frac{D_{50} T^{1.5}}{a D_{*}^{0.3}}
$$

where $D_{50}$ is the sediment diameter for which $50 \%$ of the bed material is finer; $T$ is the transport stage parameter; $a$ is the reference level; and $D *$ is a particle parameter.

In a depth-averaged two-dimensional model only the depth mean sediment concentration $S$ is available. Hence the value of the reference concentration $S_{a}$ must therefore be related to the depth mean concentration $S$, with this relationship being assumed to be of the following form ${ }^{38}$ 
13

$$
S_{a} / S=S_{a \mathrm{e}} / S_{\mathrm{e}}
$$

where $S_{\mathrm{e}}$ is the depth mean equilibrium concentration.

Substituting equation (13) into equation (11) gives:

$$
14 \quad E=w_{\mathrm{s}} \frac{S_{a \mathrm{e}}}{S_{\mathrm{e}}}\left(S_{\mathrm{e}}-S\right)
$$

Finally, as the suspended sediment concentration is assumed to be uniformly distributed over the water column, then the change rate of suspended sediment concentration caused by the non-cohesive sediment net erosion or deposition can be expressed as

\begin{tabular}{|l|l|}
\hline 15 & $\frac{\mathrm{d} S}{\mathrm{~d} t}=\frac{\boldsymbol{E}}{H}=\frac{\boldsymbol{w}_{\mathrm{s}}}{H} \frac{S_{a \mathrm{e}}}{S_{\mathrm{e}}}\left(S_{\mathrm{e}}-S\right)$ \\
\hline
\end{tabular}

If $S_{\mathrm{e}}>S$, net resuspension will occur, thus $\mathrm{d} S_{\mathrm{r}} / \mathrm{d} t=\mathrm{d} S / \mathrm{d} t$. Likewise, if $S_{\mathrm{e}}<S$, net deposition will occur, thus $\mathrm{d} S_{\mathrm{d}} / \mathrm{d} t=\mathrm{d} S / \mathrm{d} t$.

\section{BACTERIA TRANSPORT MODEL ASSOCIATED WITH SUSPENDED SEDIMENT CONCENTRATION}

\section{I. Bacterial transformation equations}

Combining equation (3) with equations (10) and (15), then the following mathematical expressions of bacteria disappearance due to settling can be obtained.

(a) For cohesive sediments

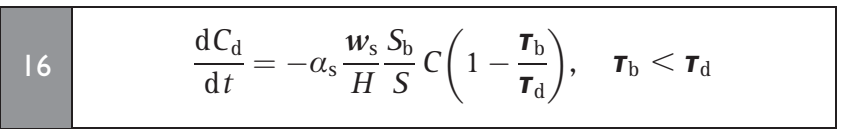

\begin{tabular}{|c|c|}
\hline 17 & $\frac{\mathrm{d} C_{\mathrm{d}}}{\mathrm{d} t}=\alpha_{\mathrm{s}} \frac{\boldsymbol{w}_{\mathrm{s}}}{H} \frac{S_{a \mathrm{e}}}{S_{\mathrm{e}}} \frac{C}{S}\left(S_{\mathrm{e}}-S\right), \quad S_{\mathrm{e}}<S$ \\
\hline
\end{tabular}

(b) and for non-cohesive sediments

As discussed in Section 1, the total disappearance of bacteria comprises two parts: the first-order decay and deposition.

For those cases where both cohesive and non-cohesive sediments are present, then equations (1), (16) and (17) can be combined to give the total bacterial disappearance rate

\begin{tabular}{|c|c|}
$\frac{\mathrm{d} C_{\mathrm{T}}}{\mathrm{d} t}=-\left\{k C+\alpha_{\mathrm{s}} \frac{\boldsymbol{w}_{\mathrm{s}}}{H} \frac{S_{\mathrm{b}}}{S} C\left(1-\frac{\boldsymbol{T}_{\mathrm{b}}}{\boldsymbol{T}_{\mathrm{d}}}\right)\right.$ \\
$\left.-\alpha_{\mathrm{s}} \frac{\boldsymbol{w}_{\mathrm{s}}}{H} \frac{S_{a \mathrm{e}}}{S_{\mathrm{e}}} \frac{C}{S}\left(S_{\mathrm{e}}-S\right)\right\}, \begin{array}{c}\boldsymbol{T}_{\mathrm{b}}<\boldsymbol{T}_{\mathrm{d}} \\
S_{\mathrm{e}}<S\end{array}$
\end{tabular}

Similarly, the following mathematical expressions can be obtained to describe the bacterial increase due to sediment resuspension from the bed.

$$
\frac{\mathrm{d} C_{\mathrm{r}}}{\mathrm{d} t}=0 \cdot 1 C_{\mathrm{b} 0} \frac{\mathrm{e}^{-k_{\mathrm{b}} t}}{H} M\left(\frac{\boldsymbol{T}_{\mathrm{b}}}{\boldsymbol{T}_{\mathrm{c}}}-1\right), \quad \boldsymbol{T}_{\mathrm{b}}>\boldsymbol{T}_{\mathrm{c}}
$$

(b) for non-cohesive sediment erosion

$$
\frac{\mathrm{d} C_{\mathrm{r}}}{\mathrm{d} t}=0 \cdot 1 C_{\mathrm{b} 0} \frac{\mathrm{e}^{-k_{\mathrm{b}} t}}{H} \frac{\boldsymbol{w}_{\mathrm{s}} S_{a \mathrm{e}}}{S_{\mathrm{e}}}\left(S_{\mathrm{e}}-S\right), \quad S_{\mathrm{e}}>S
$$

\subsection{Two-dimensional bacteria transport advective diffusion equation}

The general depth-integrated, two-dimensional governing equation for describing the sediment-linked enteric bacteria transport including the advective-diffusion processes can be written as

2) $\frac{\partial C}{\partial t}+\frac{\partial C U}{\partial x}+\frac{\partial C V}{\partial y}-\frac{\partial}{\partial x}\left[\boldsymbol{D}_{x} \frac{\partial C}{\partial x}\right]-\frac{\partial}{\partial y}\left[\boldsymbol{D}_{y} \frac{\partial C}{\partial y}\right]=\sum \Phi_{\mathrm{s}}$

where $C$ is the depth-averaged bacteria concentration (cfu/ $100 \mathrm{ml}) ; \Sigma \Phi_{\mathrm{s}}$ is the source or sink term, representing the input sources and all kinetic transformations of bacteria in the water environment. Thus the summation term on the right-hand side of equation (21) includes the processes of bacterial decay, disappearance due to deposition, entrainment from bed, and the discharge of bacteria from disposal sites, that is

$$
\Sigma \Phi_{\mathrm{s}}=\frac{\mathrm{d} C_{\mathrm{T}}}{\mathrm{d} t}+\frac{\mathrm{d} C_{\mathrm{r}}}{\mathrm{d} t}+\sum_{n=1}^{n} \frac{Q_{0} C_{\mathrm{o}}}{A_{\mathrm{o}} H}
$$

where $H$ is the water depth; $Q_{0}$ is the outfall discharge rate; $C_{0}$ is the outfall discharge concentration (cfu/100 ml); $A_{0}$ is the horizontal outfall discharge area; and $n$ is the number of outfalls.

\section{MODEL APPLICATION}

The Bristol Channel and Severn estuary are located between the coastlines of south Wales and south-west England. The model domain covers an area stretching from the seaward boundary of the outer Bristol Channel to the tidal limit of the River Severn, which includes a number of bays, rivers and the estuary (Figure 2). It receives effluents from 34 sewage outfalls coming from WwTWs and 29 riverine inputs bringing the diffuse pollution from its upstream catchments areas. ${ }^{39}$ The estuary exhibits a very high turbidity level, with a large amount of sediments being suspended and then deposited during a tidal cycle.

A dynamically linked one-dimensional and two-dimensional modelling system was refined to predict the complex hydraulic and water-quality characteristics for such a large modelling domain. As shown in Figure 2 an overlap area was used to facilitate the exchange of variables between the one- and twodimensional model regions. Limited hydrodynamic and faecal indicator data were available for this study, which were collected at four sites from a survey during the summer of 2001. Among these four sites, two of them were located near the shore, with the remaining two being away from the shore.

The model simulation was undertaken for $300 \mathrm{~h}$ to cover the 


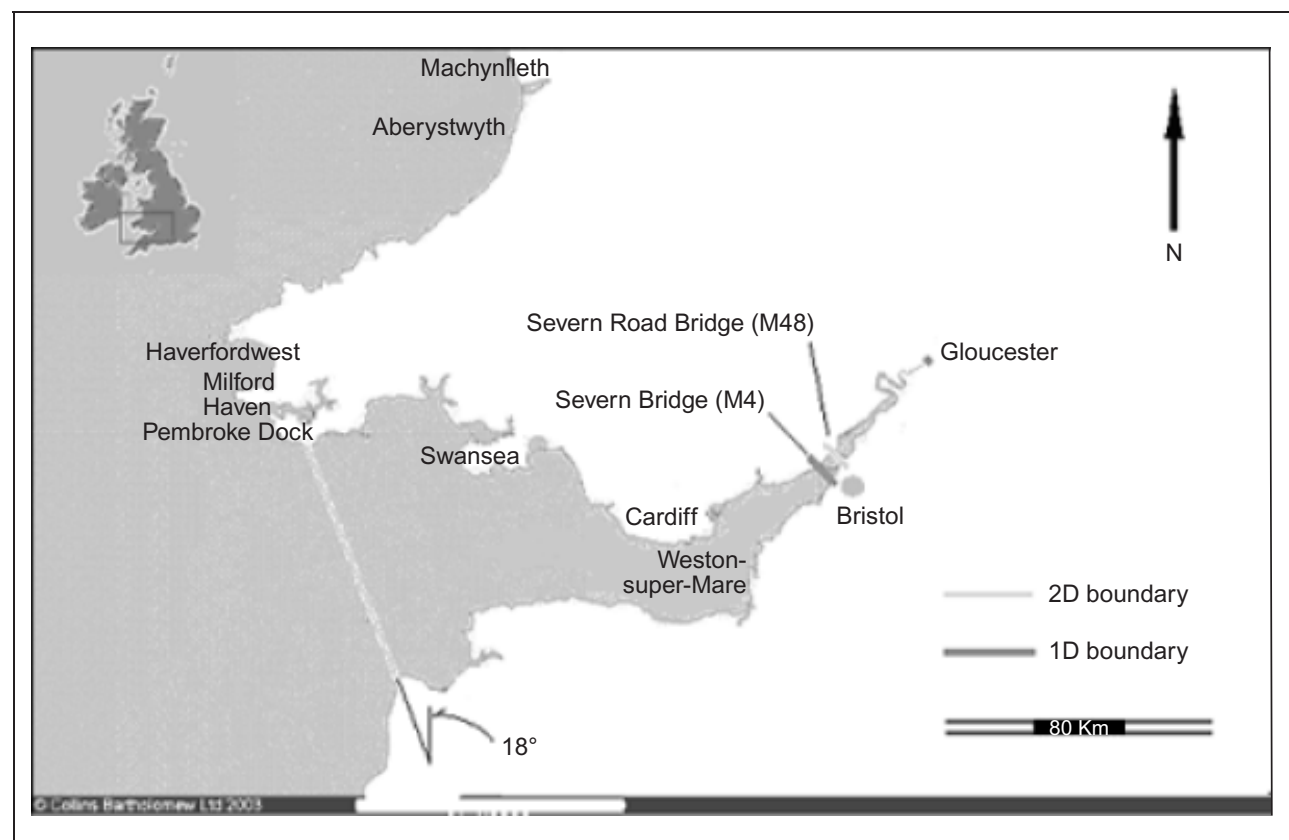

Figure 2. Study area, showing one- and two-dimensional boundaries
(Figures 6 and 7). It can be seen that the periodic variation of enterococci concentration levels caused by the tides was followed, although with phase differences. The magnitude of the error was considered acceptable for predicting enterococci concentrations. For comparison purposes, the model was also run without involving sediments; that is, assuming that bacteria existed only in the free-living phase and their concentration was controlled by transport and decay. It was found that when the sediment effect was ignored the model-predicted concentrations were much lower than the measured ones, confirming that

four field survey dates: 24, 26, 30 July and 1 August 2001. The simulation started from $1730 \mathrm{~h}$ on 20 July 2001 to reduce the possible inaccuracy in specifying the initial water level and velocity fields. For the hydrodynamic calibration the agreement between model predicted and measured data has been generally very good for all of the four survey sites. Figures 3 to 5 show typical comparisons between the predicted and measured water levels, flow speeds and directions. The level of accuracy was similar to that for other studies of the Bristol Channel. ${ }^{38}$ In order to better understand the model performance, a series of numerical model simulations were undertaken to study separately the impact of individual processes, such as sediment erosion and deposition, on the concentration distribution of enterococci bacteria. Numerical model simulations were also undertaken to study the model response to key model parameters, such as the initial conditions, population ratio of attached bacteria to total bacteria $\left(\alpha_{\mathrm{s}}\right)$ and decay rate.

Model simulation was then undertaken to predict the enterococci concentration distributions for the four survey events. Generally speaking, relatively good agreement was achieved between the predicted and measured enterococci concentrations, particularly for the two near-shore sites

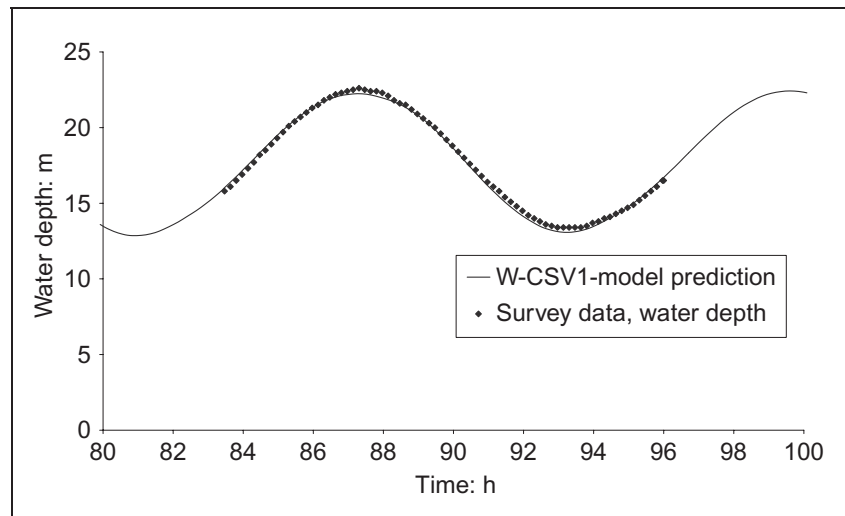

Figure 3. Comparison between predicted and measured water depths sediment erosion was one of the main sources of pollution. It should be noted that the two samples measured at the same time and same location yielded similar enterococci concentrations for most of the data points. At some data points, however, the two values were very different. The
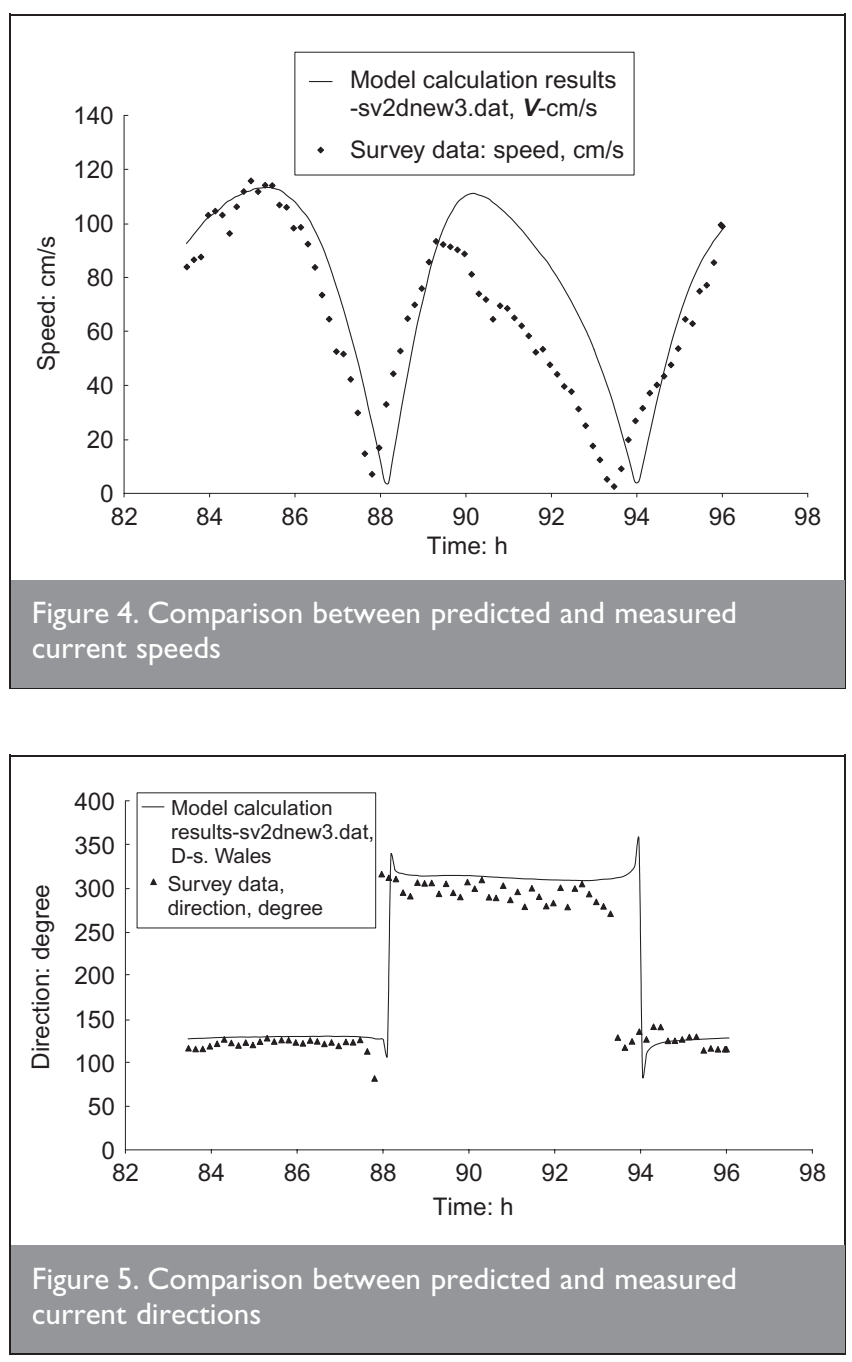


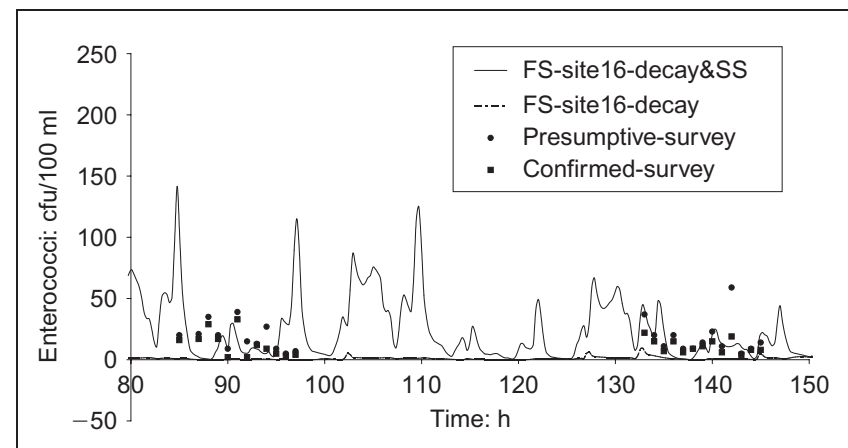

Figure 6. Comparison between predicted and observed enterococci concentrations at Trecco Bay, Porthcawl, observed data from survey one (24 July 200I) and survey two (26 July 200I)

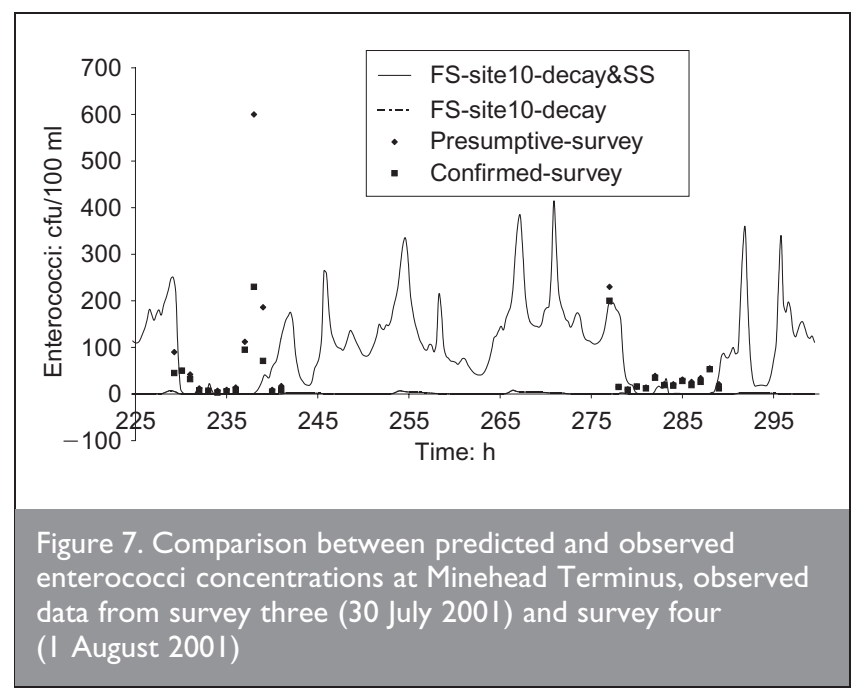

sampling and processing errors should not be ignored. It was considered that the enterococci values obtained from the second analysis (confirmed enterococci in Figures 6 and 7) were generally more reliable.

It should be mentioned that at the two offshore sites the agreement between the model predictions and the field data was not as close as the near-shore sites. This was thought to be mainly due to the fact that the measured data were collected near the water surface. At the shallower, near-shore sites the measured sediment and bacterial concentrations could be represented well by the depth mean concentrations obtained from the two-dimensional numerical model. For the two offshore sites, however, where the water depths were much greater, model-predicted sediment and concentration values could be much higher than the measured values. As a result, the predicted mean bacterial concentrations could be much higher than the measured values.

\section{CONCLUSIONS}

Details are given of the development of a conceptual model for enteric bacteria transport in coastal and estuarine waters. The aim of this study was to develop a numerical modelling tool for predicting the sediment-linked bacterial concentration levels in tidal waters. New source and sink terms were developed for inclusion in the standard two-dimensional solute transport equation. These terms can be used in practical modelling studies for unsteady and non-equilibrium flow and sediment transport conditions.

The conceptual model and mathematical formulations developed in this paper were included in a numerical model and initial tests were undertaken by applying the model to the Severn estuary. The reduction of faecal indicator population levels caused by the bacteria die-off process and the sedimentation process were modelled individually via separate first-order decay and sediment transport equations. Similarly, the increase of faecal indicator population levels due to effluent discharges from WwTWs and riverine inflows and the entrainment of bed sediments were modelled separately. The resuspension of bed sediments has shown to have an impact on the enterococci population level, particularly at the shallow water sites.

The transport and decay/growth of enteric bacteria in estuarine and coastal waters are very complex processes. The study reported in this paper was mainly focused on the development of conceptual and numerical models to represent the impact of sediments on these processes. The application of the model was based on a limited amount of data for a particular site. Further field- and laboratory-based research studies need to be undertaken in order to acquire a better understanding of the bacteria-sediments relationships both in the water column and the seabed.

\section{ACKNOWLEDGEMENTS}

The authors would like to acknowledge the financial support provided by the European Community's regional development fund (ERDF Ref. 51296). They are also grateful to Professor D. Kay, Dr C. M. Stapleton, Dr M. D. Wyer and Dr N. Humphrey for their support.

\section{REFERENCES}

1. Ghinsberg R. C., Bar Dov L., Rogol M., Sheinberg Y. and NITZAN Y. Monitoring of selected bacteria and fungi in sand and sea water along the Tel Aviv coast. Microbios, 1994, 77, 20-40.

2. Alkan U., Elliott D. J. and Evison L. M. Survival of enteric bacteria in relation to simulated solar radiation and other environmental factors in marine waters. Water Research, 1995, 29, No. 9, 2071-2081.

3. Serrano E., Moreno B., Solaun M., AurrekoetXea J. J. and IBARLUZEA J. The influence of environmental factors on microbiological indicators of coastal water pollution. Water Science and Technology, 1998, 38, No. 12, 195-199.

4. CROWTHER J., KAY D. and WYER M. D. Relationships between microbial water quality and environmental conditions in coastal recreational waters: the Flyde Coastal, UK. Water Research, 2001, 35, No. 17, 4029-4038.

5. WAIT D. A. and SOBSEY M. D. Comparative survival of enteric viruses and bacteria in Atlantic Ocean seawater. Water Sciences and Technology, 2001, 43, No. 12, $139-142$.

6. СнIск H. The process of disinfection by chemical agents and hot water. Journal of Hygiene Cambridge, 1910, 10, 237-286.

7. FaUST M. A., AOTAKY A. E. and HaRgadon M. T. Effect of physical parameters on the in situ survival of Escherichia coli MC-6 in an estuarine environment. Applied Microbiology, 1975, 30, 800-806.

8. Guilland J. F., Derrien A., Gourmelon M. and Pommepuy M. 
T90 as a tool for engineers: interest and limits. Water Sciences Technology, 1997, 35, No. 11-12, 277 $\overline{-281}$.

9. MiLNE D. P., CuRRAN J. C. and WiLSON L. Effects of sedimentation on removal of faecal coliform bacteria from effluents in estuarine water. Water Research, 1986, 20, No. 12, $1493-1496$.

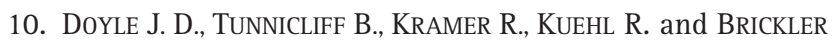
S. K. Instability of faecal coliform populations in waters and bottom sediments at recreational beaches in Arizona. Water Research, 1992, 26, No. 7, 979-988.

11. WILKINSON J., JENKINS A., WYER M. and KAY D. Modelling faecal coliform dynamics in streams and rivers. Water Research, 1995, 29, No. 3, 847-855.

12. CRABILl C., Donald R., SNelling J., Foust R. and Southam G. The impact of sediment faecal coliform reservoirs on seasonal water quality in Oak Creek, Arizona. Water Research, 1999, 33, No. 9, 2613-2171.

13. DRoste R. L. Theory and Practice of Water and Wastewater Treatment. Wiley, New York, 1997.

14. JAMieson R., Joy D. M., LeE H., KostaschuK R. and GoRdon R. Transport and deposition of sediment-associated Escherichia coli in natural streams. Water Research, 2005, 39, No. 12, 2665-2675.

15. GERBA C. P. and McLeod J. S. Effect of sediments on the survival of Escherichia coli in marine waters. Applied Environmental Microbiology, 1976, 32, No. 1, 114-120.

16. LALIBERTE P. and GRIMES D. J. Survival of Escherichia coli in lake bottom sediment. Applied Environmental Microbiology, 1982, 43, 623-628.

17. MARSHALL K. C. The effects of surfaces on microbial activity. In Water Pollution Microbiology (MitcheLl R. (ed.)). WileyInterscience, Malden, USA, 1978, vol. 2, pp. 51-70.

18. BURTON G. A., GUNNISON D. and LANZA G. R. Survival of pathogenic bacteria in various freshwater sediments. Applied Environmental Microbiology, 1987, 53, No. 4, 633-638.

19. Valiela I., Alber M. and Lmontagne M. Faecal coliform loadings and stocks in Buttermilk Bay, Massachusetts, USA, and management implications. Environmental Management, 1991, 15, No. 5, 659-674.

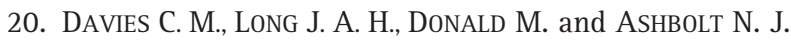
Survival of faecal microorganisms in marine and freshwater sediments. Applied Environmental Microbiology, 1995, 61, No. 5, 1888-1896.

21. BuCKLey R., Clough E., WarnKen W. and WiLd C. Coliform bacteria in streambed sediments in a subtropical rainforest conservation reserve. Water Research, 1998, 32, No. 6, $852-1856$.

22. OBIRI-DANSO K. and JoHNS K. Intertidal sediments as reservoirs for hippurate negative campylobacters, salmonellae and faecal indicators in three EU recognised bathing waters in North West England. Water Research, 2000, 34. No. 2, 519-527.

23. YANG L. Development of a Hydroinformatics Software Tool: Enteric Bacteria Transport Modelling Associated with Sediment Transport. PhD thesis, Cardiff University, UK, 2005.
24. HARVEY R. W., SMIth R. L. and GEORGE L. Effect of organic contamination upon microbial distributions and heterotrophic uptake in Cape Cod. Applied Environmental Microbiology, 984, 48, 1197-1202.

25. AlbreChTSEn H. J. Distribution of bacteria, estimated by a viable count method, and heterotrophic activity in different size fractions of aquifer sediment. Geomicrobiology Journal, 1994, 12, 253-264.

26. KRone R. B. Flume Studies of the Transport of Sediment on Estuarial Shoaling Processes. Hydraulic Engineering Laboratory, University of California, Berkeley, 1962, Report.

27. SANFORD L. P. and MAA J. P. Y. A unified erosion formulation for fine sediments. Marine Geology, 2001, 179, No. 1-2, 9-23.

28. ZIEGLER C. K. and LICK W. The transport of fine-grained sediments in shallow waters. Environmental Geological Water Sciences, 1988, 11, No. 1, 123-132.

29. MCLEAN S. R. Theoretical modelling of deep ocean sediment transport. Marine Geology, 1985, 66, No. 1-4, 243-265.

30. SANFORD L. P. and HALKA J. P. Assessing the paradigm of mutually exclusive erosion and deposition of mud, with examples from upper Cheaspeake Bay. Marine Geology, 1993, 114, No. 1-2, 37-57.

31. EINSTEIN H. A. and KRONE R. B. Experiments to determine modes of cohesive sediment transport in salt water. Journal of Geophysics Research, 1962, 67, 1451-1461.

32. Sмith J. D. Modelling of sediment transport on continental shelves. In: The Sea (GOLDBERG E. D., MCCAVE I. N., O'BRIEN J. J. and STEELE J. H. (eds)). Wiley, New York, 1977, vol. 6, pp. 539-577.

33. DYER K. R. Coastal and Estuarine Sediment Dynamics. Wiley, New York, 1986.

34. GLENN S. M. and GRANT W. D. A suspended sediment stratification correction for combined wave and current flows. Journal of Geophysics Research, 1987, 92, 82448264.

35. VAN RIJN L. C. Sediment transport, Part 1: bed load transport. Journal of Hydraulic Engineering, 1984, 110, No. 10, $1431-1456$.

36. VAN RIJN L. C. Sediment transport, Part 2: suspended load transport. Journal of Hydraulic Engineering, 1984, 110, No. 11, 1631-1641.

37. CARCIA M. and PARKER G. Entrainment of bed sediment into suspension. Journal of Hydraulic Engineering, 1991, 117, No. 4, 414-435.

38. LIN B. and FALCONER R. A. Modelling sediment fluxes in estuarine waters using a curvilinear coordinate grid system. Estuarine, Coastal and Shelf Science, 1995, 41, No. 4, 413428.

39. Kay D., Stapleton C. M., Wyer M. D., McDonald A. T., Crowther J., PAUl N., Jones K., Francis C., Watkins J., WiLKINSON J., NUMPHREY N., LIN B., YANG L., FALCONER R. A. and GARDNER S. Decay of intestinal enterococci concentrations in high-energy estuarine and coastal waters: towards real-time T90 values for modelling faecal indicators in recreational waters. Water Research, 2005, 39, No. 4, 655-667.

\section{What do you think?}

To comment on this paper, please email up to 500 words to the editor at journals@ice.org.uk

Proceedings journals rely entirely on contributions sent in by civil engineers and related professionals, academics and students. Papers should be 2000-5000 words long, with adequate illustrations and references. Please visit www.thomastelford.com/journals for author guidelines and further details. 